\title{
Identification of Auxin from Pseudomonas sp. P7014 for the Rapid Growth of Pleurotus eryngii Mycelium
}

\author{
Young Min Kang ${ }^{1}$ and Kye Man Cho ${ }^{2 *}$ \\ ${ }^{1}$ Herbal Medicine Resources Group, Herbal Medicine Research Division, \\ Korean Institute of Oriental Medicine (KIOM), Daejeon 305-811, Republic of Korea \\ ${ }^{2}$ Department of Food Science, Gyeongnam National University of Science and Technology, \\ Jinju 660-758, Republic of Korea

\section{큰느타리버섯 균사체의 생육촉진을 위한 Pseudomonas sp. P7014으로부터 옥신 확인}

\author{
강영민 ${ }^{1} \cdot$ 조계만 ${ }^{2 *}$ \\ ${ }^{1}$ 한국한의학연구원 한약연구본부 한약자원그룹 \\ ${ }^{2}$ 경남과학기술대학교 식품과학부
}

(Received October 28, 2013 / Accepted March 10, 2014)

\begin{abstract}
The promoting effect of Pseudomonas sp. P7014 on the mycelia growth of Pleurotus eryngii was investigated. An ethyl acetate fraction (F5) from the culture supematant of the bacteria was confirmed to contain the growth promoting compound (GPC). The GPC was identified to be indole acetic acid (IAA) by TLC, HPLC, MS/MS, and NMR analyses. $P$. eryngii mycelia grew rapidly both on PDA and in PDB after the treatment of GPC. The promoting concentration of GPC was as low as $1.0 \mathrm{nM}$. Tryptophan, the aminated form of IAA, was confirmed to be the precursor of IAA. These results suggested that bacterial secreted compound was IAA and plays an important role in promoting growth of mushroom mycelia.
\end{abstract}

Keywords: Pleurotus eryngii, Pseudomonas sp. P7014, bioassay, growth promotion, indole acetic acid

King oyster mushroom (Pleurotus eryngii) is the third largest commercially produced mushroom (Bano and Rajarathnnam, 1987; Obodai et al., 2003) in the world. The increasing popularity of Pleurotus mushroom among consumers is not only due to its flavor, texture and shelf life but also to immunomodulating and oxidative enzyme production (Mark et al., 2004; Silva et al., 2005). In the cultivation of Pleurotus mushrooms, the biological properties of composts appear to be very important for inducing fruiting body formation. At least one mushroom species, Agaricus bisporus, growth and development are particularly affected by bacteria of the family Pseudomonadaceae (Grewal and Rainey, 1991). In addition, Cho et al. (2003) report that fluorescent pseudomonads promote the growth of Pleurotus sp. Representatives of the genus Pseudomonas are common in soil and on plants, and a few are associated with mushrooms. There

*For correspondence. E-mail: kmcho@gntech.ac.kr; Tel.: +82-55-7513272; Fax: +82-55-751-3279 are numerous reports on the improvement of plant growth and crop yield upon inoculation with rhizosphere bacteria. The observed plant response to bacterial inoculation is attributed to the production of bacterial indole-3-acetic acid (IAA) (Barbieri and Galli, 1993; Okon and Vanderleyden, 1997). Unlike plants, mushrooms cannot synthesize auxins endogenously. However, the hormonal effects of auxins on mushrooms can be elucidated by studying exogenous effects. There is also ample evidence that numerous soil micro-organisms are actively involved in the synthesis of auxins in pure culture and in soil (Arshad and Frankenberger, 1998; Barazani and Friedman, 1999; Biswas et al., 2000).

Pleurotus sajor-caju is cultured under submerged condition with plant growth hormones (indole-3-acetic acid, gibberellic acid, and kinetin) and twenty-eight percent more enhancements are observed with indole-3-acetic acid (Mukhopadhyay et al., 2005). Wang et al. (2009) and Wang et al. (2010) report that the aposymbiotical growths of Ramaliana farinacea and $R$. 
fastigiata are increased by plant hormones (indole-2-butyric acid and 2,3,5-tri-dobenzoic acid) on malt-yeast extract medium and the growths of lichen-forming fungi (Nephromopsis ornata, Myelochroa irrugans, and Usnea longissima) are promoted by plant hormones (auxin, abscisic acid, cytokine, and gibberellin), respectively. In contrast, there are a few reports on the improvement of mushroom growth upon inoculation with bacteria and very few of these are attributed to the production of IAA by bacteria.

IAA is the most important naturally occurring auxin and is implicated in many aspects of plant growth and development. Promotion of root growth is one of the beneficial effects of plant growth-promoting bacteria (Glick et al., 1995). Most root-promoting bacteria synthesize IAA and their effects on plants mimic that of exogenously applied IAA. L-tryptophan (L-TRP), an amino acid, serves as a physiological precursor for the biosynthesis of auxins in plants and microbes (Frankenberger and Arshad, 1995).

Although many reports suggested that the addition of different pseudomonas species may have a beneficial effect on mushroom mycelium growth, the active factor or factors have not been conclusively identified. We examined bacterial extracts in order to identify compounds responsible for growth promotion. The work presented here is details an investigation of factors that are involved in enhancing Pleurotus eryngii mycelium growth secreted by bacteria.

\section{Materials and Methods}

\section{Media, culture conditions, and growth promoting test of bacterium}

A bacterium, Pseudomonas sp. P7014, used in this study was previously described by Kim et al. (2008) and identified by 16S rRNA analysis (GenBank accession no. EF154396). The effects of its culture supernatant on $P$. eryngii mycelium growth were examined as described previously (Kim et al., 2008).

\section{Extraction and identification of growth promoting compound (GPC)}

Filtered mycelia of $P$. eryngii were dried and weighed. The dry mass of mushroom mycelium, were grown in potato dextrose (PD, Becton Dickinson Co., USA) containing a range of GPC prepared concentration. Inoculated flasks were incubated at $25^{\circ} \mathrm{C}$ for 15 days. Bacteria in culture of Pseudomonas sp. P7014 were pelleted by centrifugation at $(8,000 \times \mathrm{g})$ for $30 \mathrm{~min}$. The supernatant was then mixed with an equal volume of ethyl acetate and extracted by the procedure outlined in Tien et al. (1979). The extracts (ethyl acetate extraction) were filtered through a $0.45 \mu \mathrm{m}$ membrane filter in preparation for analytical thin layer chromatography (TLC), high-pressure liquid chromatography (HPLC). Additionally, the GPC was analyzed by LC-mass spectrometry (MS) and nuclear magnetic resonance (NMR).

TLC was done using aluminum silica gel 60 (Merck). The solvent system was ethyl acetate:isopropanol:ammonium hydroxide [45:35:20 (v/v)] to separate indole compounds. Specifically indole acetic acid (IAA, Sigma-Aldrich Co., USA) was detected on TLC plates by Salkowski's reagent $\left(\mathrm{H}_{2} \mathrm{SO}_{4}\right.$ $\left.150 \mathrm{ml}+\mathrm{H}_{2} \mathrm{O} 250 \mathrm{ml}+0.5 \mathrm{M} \mathrm{FeCl}_{3} \cdot 6 \mathrm{H}_{2} \mathrm{O} 7.5 \mathrm{ml}\right)$ staining. The TLC bands were extracted with methanol (Fisher Scientific Co., USA); further eluted quantified fractions were diluted with sterile water for getting appropriate concentration and tested for effectiveness by plate assay in PD agar medium. For each 100 $\mathrm{ml}$ of medium, $1 \mathrm{ml}$ of an ethyl acetate fraction or $2 \mathrm{ml}$ of eluted fraction, respectively, were added. Plates were then inoculated with a mycelium containing PDA block and incubated for 12 days at $25^{\circ} \mathrm{C}$ with $65 \pm 5 \%$ humidity.

For preparation of the compound fraction, the corresponding spots were scratched out of the thin-layer chromatograms, and the silica gel material was extracted with methanol. For further purification, $1 \mathrm{mg}$ of extract was subjected to reversed phase high performance liquid chromatography (RP-HPLC; LC-908, JAIGEL-1H column, Japan Analytical Industry, Japan). The mobile phase for elution was acetonitrile/water $(1: 1, \mathrm{v} / \mathrm{v})$ (Fisher Scientific Co.) at a flow rate of $2.5 \mathrm{ml} / \mathrm{min}$ and the absorbance of the separated IAA containing fractions were measured at $280 \mathrm{~nm}$.

The GPC was analyzed by LC-mass spectrometry (MS) and nuclear magnetic resonance (NMR). Fractions containing tentative IAA (as determined by comparison with the retention time of authentic IAA) were pooled, concentrated, dissolved in $100 \mu \mathrm{CDCl}_{3}$ and transferred for NMR at $300 \mathrm{MHz}$ (Bruker DRX-600 equipped with a 2.5-mm SEI microprobe, Bruker Co., Germany). NMR data from ${ }^{13} \mathrm{C}$ NMR experiments was used to identify IAA by comparison with NMR data recorded from IAA standards. The isolated tentative IAA was also analyzed by MS/MS in the positive mode (Esquire LC ion trap mass spectrometer, equipped with an electrospray ion source, Bruker Daltonik, Bruker Co.). Samples were dissolved in methanol/water (1:1) and injected using a syringe pump at 1 $\mu 1 / \mathrm{min}$. The scan range was $100-500 \mathrm{~m} / \mathrm{z}$ and the results from ten mass spectra were averaged. For MS operation the ion accumulation time was $1 \mathrm{~ms}$, whereas for MS/MS operation the ion accumulation time was $30 \mathrm{~ms}$.

\section{Quantification of indole acetic acid (IAA) production}

IAA production in wild-type P7014 strain was studied as previously described (Glick and Patten, 2002). GP Media 
(Glucose 40/g; peptone 10/g medium) was used along with DF salt minimal medium (Glick and Patten, 2002). The concentration of IAA in each culture medium was determined by comparison with a standard curve. As well as, filtered supernatant was analyzed by using HPLC and IAA was quantified by integrating the areas under the peaks comparing to authentic standard IAA. IAA production by P7014 strain was measured in triplicate.

HPLC was carried out by injecting $10 \mu \mathrm{l}$ of the filtered extract onto a reverse-phase $\mathrm{C}_{8}$ colum $(4.6 \times 250 \mathrm{~mm}$, Brownlee, Applied Biosystems) on PerkinElmer Series 200 series HPLC (Perkin-Elmer Co., USA). Samples were eluted at a flow rate of $1 \mathrm{ml} / \mathrm{min}$ using $0.5 \%$ acetic acid and methanol $(65: 35[\mathrm{v} / \mathrm{v}])$ with an operating pressure of 140 Bar. The absorbance of the separated IAA containing fractions were measured at $280 \mathrm{~nm}$ and quantified by comparing IAA standards to bacterial cultures by UV detection (Perkin-Elmer 200 series, Perkin-Elmer Co.).

\section{Statistical analysis}

All values are means of determinations in three independent experiments. Differences in the means of each value were determined by one-way ANOVA followed by the Tukey's multiple range tests at $P<0.05$ using the Statistical Analysis System software, Version 9.0 (SAS Institute, USA).

\section{Results and Discussion}

\section{Identification of growth promoting compound (GPC) from Pseudomonas sp. P7014}

Ethyl acetate fractions from a Pseudomonas sp. P7014 supernate exhibited a growth promoting effect on mushroom mycelia compared to control plate in reproducible manner. TLC of the ethyl acetate extract from the culture supernatant of
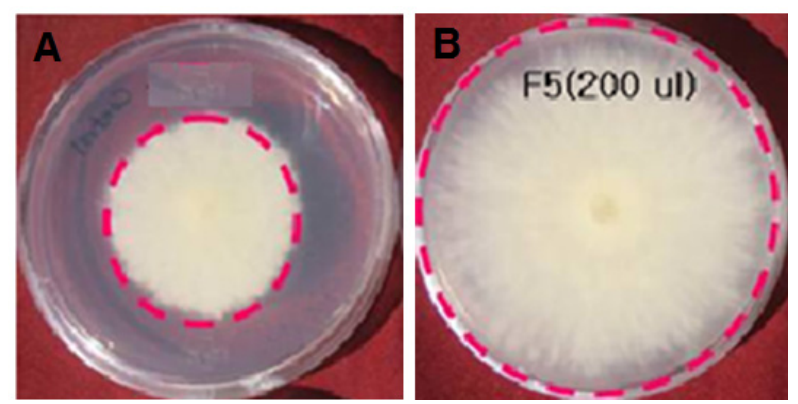

Fig. 2. Effect of $P$. ergyii mycelium growth by the treated growth promoting compound (GPC). (A) Control and (B) ethyl acetate fraction No. 5 (F5). F5 was scratched out of the thin-layer chromatograms, and the silica gel material was extracted with methanol. The extractions were added approximately $200 \mu \mathrm{l}$ on PDA and dropped on P. ergyii mycelium.
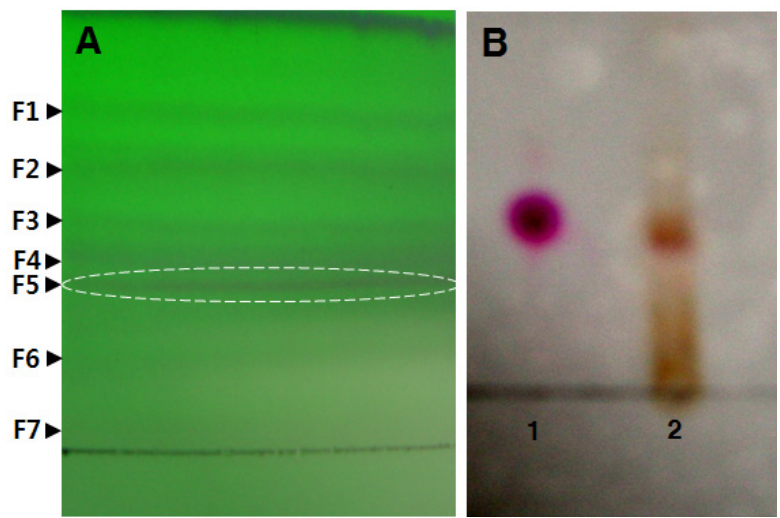

Fig. 1. TLC patterns of ethyl acetate extraction and fraction No. 5 (F5). (A) TLC patterns of ethyl acetate extraction and (B) TLC patterns of IAA standard and ethyl acetate fraction No. 5 (F5) by the treated with Salkowski's reagent. 1, IAA standard; 2, fraction No.5. The fraction was characterized by clear reddish pink spot at the $R_{f} 0.34$ corresponding to IAA.

Pseudomonas sp. P7014 strain consistently showed seven spotting band (Fig. 1A), and interestingly band No.5 (F5) was characterized by a clear reddish pink spot at the $R_{f} 0.34$ corresponding to IAA, when the chromatogram was treated with Salkowski's reagent (Fig. 1B). The F5 fraction of ethyl acetate exhibited the most impressive positive effect on mycelium growth (Fig. 2), whereas direct addition of extract caused growth inhibition. GPC inhibited mycelium growth in the $\mathrm{mM}$ concentration range, but promoted growth in the $\mathrm{nM}$ concentration range (Fig. 3). Meanwhile, P. eryngii mycelia grown in PD broth in the presence of bacterial GPC also increased in dry mass at $\mathrm{nM}$ concentration. The dry mass of mycelia grown in the flask is shown in Fig. 3. P. eryngii

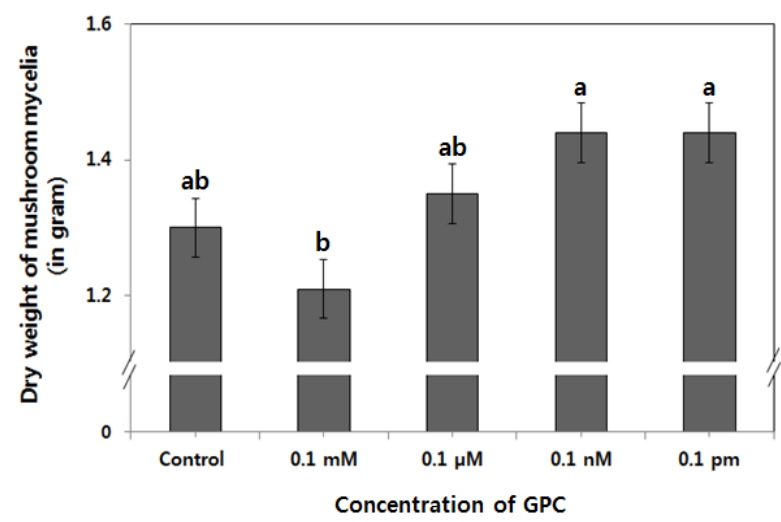

Fig. 3. Growth effect of $P$. ergyii mycelium by the different concentrations of growth promoting conpound (GPC). All values are means of determinations in three independent experiments. Means with different lowercase letters $(a$ and $b$ ) indicate significant differences of fermentation times by Tukey's multiple range test $(P<0.05)$ 
mycelia grown in PD broth in the presence of bacterial GPC might have a significant improvement in biological efficiency. An economically attractive species of commercial strains such

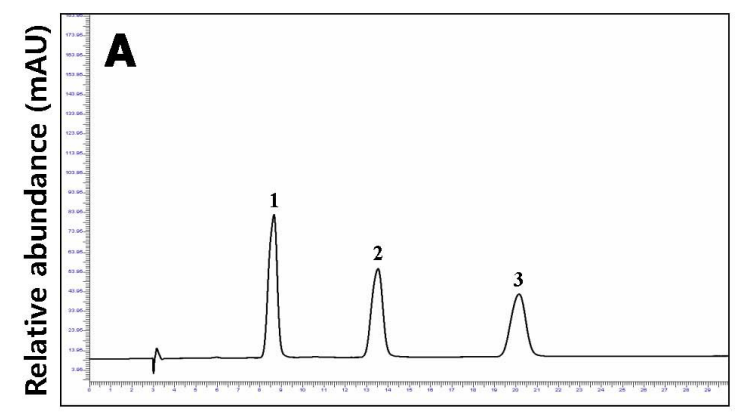

Retention time (min)

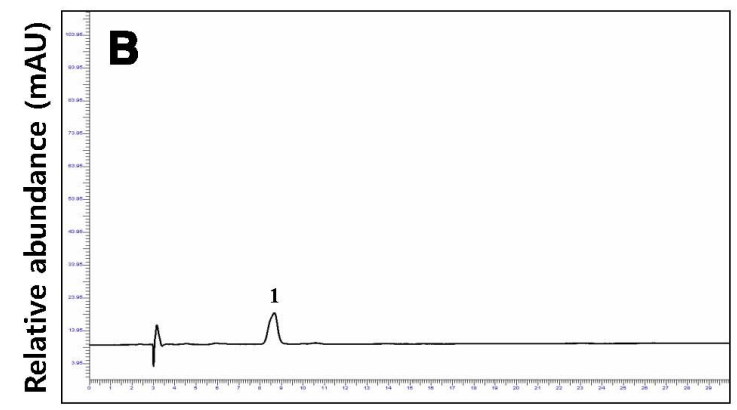

Retention time (min)

Fig. 4. Typical HPLC chromatograms of indole compounds. (A) Three indole compound standards as following: 1, indole acetic acid (IAA); 2, indole propone acid (IPA); 3, indole butyric acid (IBA) and (B) Separation of IAA from ethyl acetate fraction No. 5 (F5) of P7014 strain. as Agrocybe cylindracea was a significant improvement in biological efficiency because $A$. cylindracea relatively had higher yield than the dry substrate weight (Uhart et al., 2008).

The GPC was followed by TLC and HPLC through extraction and purification. A HPLC chromatogram of the ethyl acetate fraction is shown in Fig. 4. The peak at 8.40 min was seen in the analytical chromatogram of the ethyl acetate extract. The level of IAA was present at concentration of $31.8 \mu \mathrm{g} / \mathrm{ml}$ on F5 fraction of ethyl acetate. This indicated that the substance might be IAA. A TLC spot was extracted in methanol and compounds were purified by preparative HPLC revealing peak at 8.27 min corresponding to IAA (based on comparisons with standard IAA). This peak was collected for further analysis.

The ${ }^{13} \mathrm{C}$ NMR data for the selected fractions isolated from P7014 strain was identical to the NMR data recorded for the IAA standard (data not shown). The MS-data showed an ion at $m / z 175$ consistent with the $m / z$ of IAA in the proton adduct form $\left[\mathrm{M}+\mathrm{H}^{+}\right]$. When the ion at $m / z 175$ was subjected to MS/MS analysis, the main fragment ion formed was $m / z 130$, consistent with the presence of an indole ring an acetate group ( Fig. 5). MS/MS analysis of the IAA standard yielded similar data. Thus, both NMR and MS data confirm the presence of IAA in the strains studied.

In order to check the effect of the treated IAA on mycelial growth of $P$. ergyii, the mycelia growth at specific incubation period was very important. The mycelium could be developed as germination, elongation, saturation, and dormancy. The period between elongation and saturation on the mycelia

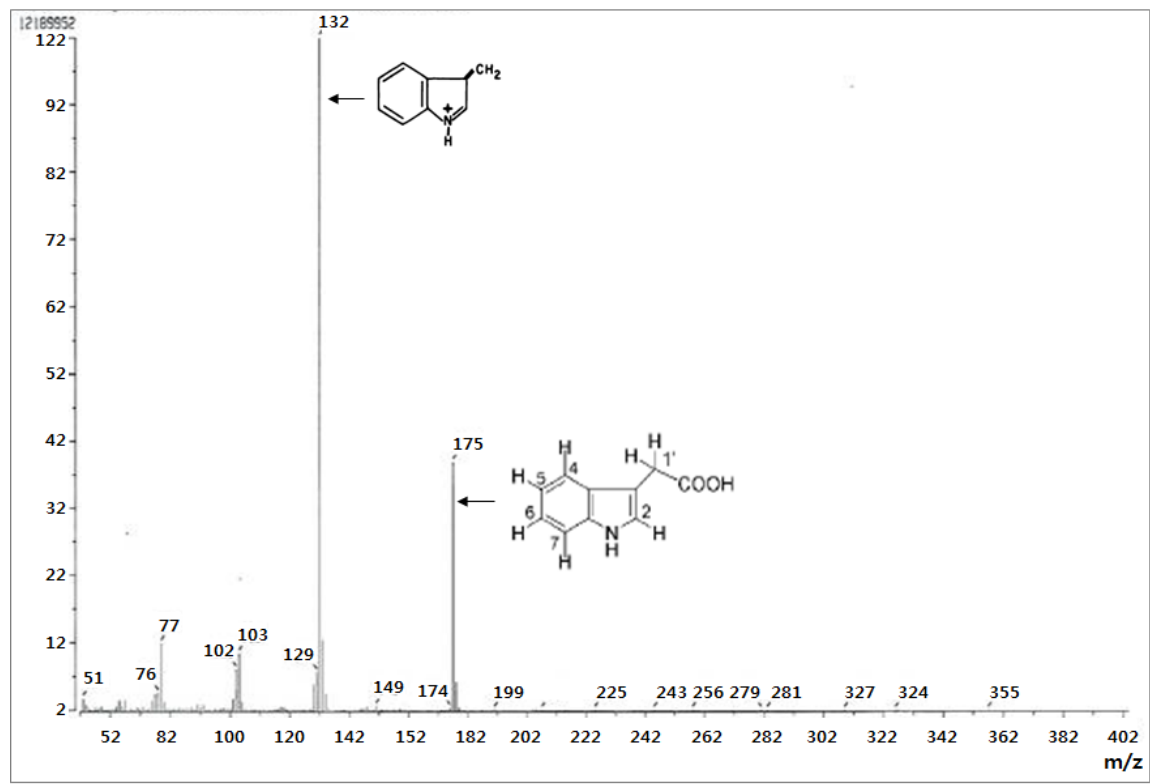

Fig. 5. MS spectrum of the HPLC purified growth promoting compound (GPC) fraction. Fragmentation of the protonated ions, $m / z 130$ representing indole along with acetate groups and $\mathrm{m} / \mathrm{z} 175$, unionized indole acetic acid. 
Table 1. IAA Production by Pesudomonas sp. P7014 in the presence of various concentrations of tryptophan among DF and GP medium.

\begin{tabular}{ccc}
\hline \multirow{2}{*}{$\begin{array}{c}\text { Tryptophan concentration } \\
(\mu \mathrm{g} / \mathrm{ml})\end{array}$} & \multicolumn{2}{c}{ IAA $\left(\mu \mathrm{g} / \mathrm{ml}^{\prime} / \mathrm{OD}_{600}\right)^{\mathrm{l})}$} \\
\cline { 2 - 3 } 50 & $0.8 \pm 0.1^{\mathrm{d}}$ & $1.6 \pm 0.01^{\mathrm{d}}$ \\
\hline 50 & $16.1 \pm 0.6^{\mathrm{b}}$ & $20.1 \pm 0.4^{\mathrm{b}}$ \\
200 & $24.5 \pm 0.2^{\mathrm{b}}$ & $29.9 \pm 0.7^{\mathrm{ab}}$ \\
500 & $28.3 \pm 0.8^{\mathrm{ab}}$ & $36.6 \pm 0.3^{\mathrm{a}}$ \\
\hline
\end{tabular}

${ }^{1)}$ All values are means of determinations in three independent experiments. Means with different lowercase letters $(a, b, c$, and $d)$ indicate significant differences of fermentation times by Tukey's multiple range test $(P<0.05)$.

growth of $P$. ergyii was about 15 days (before saturation point of mycelium) (Kim et al., 2008). The mycelial growth of $P$. ergyii at incubation period for 15 days was tested and mycelia growth ratio of $P$. ergyii during incubation periods was represented on Fig. 6. During incubation period, the mycelia growth of $P$. ergyii was higher on the treated IAA than on the control.

Though there are a few reports suggesting that IAA inhibits the growth of Saccharomyces cerevisiae (Peck and Kende, 1995). Perhaps high levels of exogenous or bacterial IAA can also inhibit growth. Meanwhile, high levels of ethylene have also been shown to inhibit root elongation (Wood and Hammond, 1977; Loper and Schroth, 1986; Barbieri and Galli, 1993; Sawar and Kremmer, 1995; Xie et al., 1996; Beyerler et al., 1997; Rahman et al., 2001). It provided evidence of
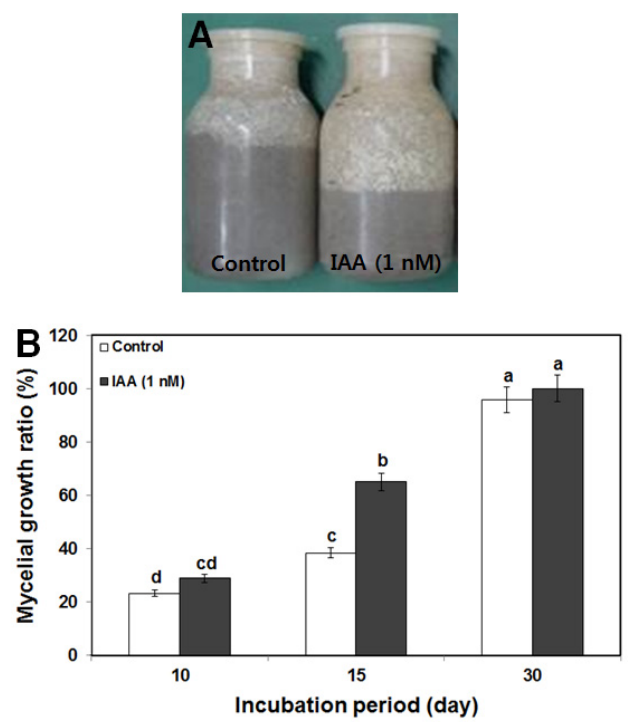

Fig. 6. Effect of the treated IAA on mycelial growth of P. ergyii. (A) Photograph of mycelial growth of $P$. ergyii at incubation period 15 days and (B) mycelial growth ratio of $P$. ergyii during incubation periods. All values are means of determinations in three independent experiments. Means with different lowercase letters (a, b, c, and d) indicate significant differences of fermentation times by Tukey's multiple range test $(P<0.05)$. ethylene production at the time of mushroom metabolism in $A$. bisporus. We showed that the bacterium P7014 produce a compound that exhibits a positive effect on growth. IAA produced by $\mathrm{P} 7014$ strain probably exhibit same kind of effect on mycelium growth at $\mathrm{nM}$ concentrations, but inhibitory effect at $\mathrm{mM}$ concentrations. In plants it is known that primary root growth is stimulated by low levels of IAA, typically between $10^{-9}$ and $10^{-12} \mathrm{M}$ (Pilet and Saugy, 1987; Alvarez et al., 1989; Meuwley and Pilet, 1991), and is inhibited by higher IAA concentration, likely via auxin induced ethylene (Peck and Kende, 1995). Although Pseudomonas sp. P7014 is capable of IAA biosynthesis, the growth effect of P. ergyii mycelium has slightly differences by the treatment of P7014 (Kim et al., 2008) and GPC. There results are guessed that may be some other factor also involved in growth promotion.

\section{Indole acetic acid (IAA) production of Pseudomonas sp. P7014}

Like other mushroom growth promoting bacteria, strain P7014 synthesize high levels of IAA as tryptophan concentration was increased (ranging from $0-500 \mu \mathrm{l} / \mathrm{ml}$ in culture medium). Interestingly, IAA production increased in the GP medium culture, compared to production in DF salt medium (Table 1). Culture in the absence of tryptophan resulted in low IAA levels. Measurement of IAA by HPLC confirmed that high tryptophan concentrations (more than $500 \mu \mathrm{l} / \mathrm{ml}$ ) have little influence on IAA production. This is in agreement with other results showing that this amino acid is simply a basic precursor for IAA synthesis in most studied IAA-producing bacteria.

Tryptophan is a precursor for bacterial IAA biosynthesis (Steenhoudt and Vanderleyden, 2000; Eckardt, 2001). As expected, higher amount of IAA production was possible with increased tryptophan concentration ( 0 to $500 \mu \mathrm{g} / \mathrm{ml}$ ) for P7014 strain, as is the case for most of the other plant growth promoting bacteria. Pseudomonas sp. P7014 produced a supernatant compound which promoted the growth of mushroom mycelia. The supernatant compound was extracted with ethyl acetate and separated by TLC, and after each step a positive effect was 
observed. Meanwhile, structural studies were done using different analytical instruments (HPLC, NMR, and MS/MS) and the results suggested that the factor responsible for growth was an auxin compound.

IAA is well a known growth promoting phytohormone, produced by many bacteria. Likewise to plant growth promoting bacterium, tryptophan influenced strain P7014 bacteria to produce high amount of IAA in culture medium than bacteria grown without tryptophan. Likewise, IAA plays same kind of role in stimulating mycelia of mushroom. The present results, the growth of $\mathrm{P}$. ergyii mycelium were observed by the bacterial GPC $(>0.1 \mathrm{nM})$, this suggests that it might be due to the influence of IAA.

In conclusion, our findings suggest that Pseudomonas sp. P7014 promoted mycelium growth by producing the IAA. The data obtained unambiguously demonstrate the presence of IAA in the supernatant of strain P7014 cultures. The widely used Salkowsky reagent is not specific to IAA, but can also react with other indole derivatives such as indole-3-acetamide and indole-3-pyruvic acid, which belong to the auxins, therefore production of other auxins by P7014 strain cannot be ruled out. This possibility is also indicated by the observation that the HPLC-based estimation of IAA concentrations gave lower values compared to the colorimetric method (data not shown) (Omer et al., 2004). Production of IAA in bacteria may have evolved because it was important in the bacterium-mushroom relationship. In this research we showed that bacterial IAA stimulated the development of host mushroom mycelia. The details of a potential relationship between bacteria and mushroom are stimulating for future initiatives.

\section{적 요}

Pseudomonas sp. P7014 박테리아를 통한 큰느타리버섯 균사 체의 생육촉진에 관한 연구가 수행되었다. 박테리아 배양액으로 부터 분리한 ethyl acetate 분획물(F5)에는 성장촉진물질(GPC) 이 함유되어 있음을 확인하였다. TLC, HPLC, NMR 및 MS/MS 분석법으로 확인한 바, indole acetic acid (IAA)로 확인되었다. 큰느타리버섯 균사체는 성장촉진물질(GPC)이 첨가된 $\mathrm{PDA}$ 와 $\mathrm{PDB}$ 배지에서 빠른 성장을 보였다. 성장촉진물질 $(\mathrm{GPC})$ 의 농도 는 $1.0 \mathrm{nM}$ 로 매우 낮았지만, 확인된 tryptophan은 IAA의 전구체 로써 IAA가 아민화된 형태였다. 이들 결과는 박테리아에서 분 비된 성장촉진물질(GPC)은 IAA이었고 큰느타리버섯 균사체의 생육촉진에 중요한 역할을 하는 것으로 확인되었다.

\section{Acknowledgements}

This research was supported by Gyeongnam National University of Science and Technology Grant (2013).

\section{References}

Alvarez, R., Nissen, S.J., and Sutter, E.G. 1989. Relationship between indole-3-acetic acid levels in apple (Malus pumila Mill.) rootstocks cultured in vitro and adventitious root formation in the presence of indole-3-butyric acid. Plant Physiol. 89, 439-443.

Arshad, M. and Frankenberger, W.T.Jr. 1998. Plant growth regulating substances in the rhizosphere: microbial production and functions. Advan. Agron. 62, 146-151.

Bano, Z. and Rajarathnnam, S. 1987. Pleurotus mushroom, part IA. Morphology, life cycle, taxonomy, breeding and cultivation. Crit. Rev. Food Sci. Nutr. 26, 157-233.

Barazani, O. and Friedman, J. 1999. Is IAA the major root growth factor secreted from plant-growth-mediating bacteria? J. Chem. Ecol. 25, 2397-2406.

Barbieri, R. and Galli, E. 1993. Effect on wheat root development of inoculation with an Azospirillum brasilense mutant with altered indole-3-acetic acid production. Res. Microbiol. 144, 69-75.

Beyerter, M., Michaux, P., Keel, C., and Haas, D. 1997. Effect of enhanced production of indole-3-acetic acid by the biological control agent Pseudomonas fluorescens $\mathrm{CHA} 0$ on plant growth, pp. 310-312. In Ogoshi, A., Kobayashi, K., Homma, Y., Kodama, F., Kondo, N., and Akino, S. (ed.), Plant growthpromoting rhizobacteria: present status and future prospects. OECD, Paris, France.

Biswas, J.C., Ladha, J.K., and Dazzo, F.B. 2000. Rhizobia inoculation improves nutrient uptake and growth of lowland rice. Soil Sci. Soc. Am. J. 64, 1644-1650.

Cho, Y.S., Kim, J.S., Crowley, D.E., and Cho, B.G. 2003. Growth promotion of the edible fungus Pleurotus ostreatus by fluorescent pseudomonads. FEMS Microbiol. Lett. 218, 271-276.

Eckardt, N.A. 2001. New insights into auxin biosynthesis. Plant Cell. $13,1-3$.

Frankenberger, W.T. and Arshad, M.Jr. 1995. Phytohormones in soil: Microbial production and function, p. 503. Marcel Dekker Inc., NY, USA.

Glick, B.R., Karaturovic, D.M., and Newell, P.C. 1995. A novel procedure for rapid isolation of plant growth promoting pseudomonads. Can. J. Microbiol. 41, 533-536.

Glick, B.R. and Patten, C.L. 2002. Role of Pseudomonas putida indoleacetic acid in development of the host plant root system. Appl. Environ. Microbiol. 68, 3795-3801.

Grewal, S.I. and Rainey, P.B. 1991. Phenotypic variation of Pseudomonas putida and P. tolaasii affects the chemotactic response to Agaricus bisporus mycelial exudate. J. Gen. Microbiol. 137, 2761 $-2768$

Kim, M.K., Math, R.K., Cho, K.M., Shin, K.J., Kim, J.O., Ryu, J.S., Lee, Y.H., and Yun, H.D. 2008. Effect of Pseudomonas sp. P7014 on the growth of edible mushroom Pleurotus eryngii in bottle culture for commercial production. Bioresour. Technol. 99, 3306-3308.

Loper, J.E. and Schroth, M.N. 1986. Influence of bacterial sources of indole-3-acetic acid on root elongation of sugar beet. J. Phytopathol. 76, 386-389.

Mark, S., Valentina, K., Yulia, M., Alexander, G., Andrey, P., Andrey, S., Nikolay, P., and Nina, D. 2004. Immunomodulating and anti-tumor action of extracts of several mushrooms. J. Biotechnol. 113, 77-83.

Meuwley, P. and Pilet, P.E. 1991. Local treatment with indole-3-acetic acid induces differential growth responses in Zea mays L. roots. 
Planta 185, 58-64.

Mukhopadhyay, R., Chatterjee, S, Chatterjee, B.P., and Guha, A.K. 2005. Enhancement of biomass production of edible mushroom Pleurotus sajor-caju grown in whey by plant growth hormones. Process Biochem. 40, 1241-1244.

Obodai, M., Cleland-Okine, J., and Vowotor, K.A. 2003. Comparative study on the growth and yield of Pleurotus ostreatus mushroom on different lignocellulosic by-products. J. Ind. Microbiol. Biotechnol. 30, 146-149.

Okon, Y. and Vanderleyden, J. 1997. Root-associated Azospirillum species can stimulate plants. ASM News 63, 366-370.

Omer, Z.S., Tombolini, R., Broberg, A., and Gerhardson, B. 2004. Indole-3-acetic acid production by pink-pigmented facultative methylotrophic bacteria. Plant Growth Regul. 43, 93-96.

Peck, S.C. and Kende, H. 1995. Sequential induction of the ethylene biosynthetic enzymes by indole-3-acetic acid in etiolated peas. Plant Mol. Biol. 28, 293-301.

Pilet, P.E. and Saugy, M. 1987. Effect on root growth of endogenous and applied IAA and ABA. Plant Physiol. 83, 33-38.

Rahman, A., Amakawa, T., Goto, N., and Tsurumi, S. 2001. Auxin is a positive regulator for ethylene-mediated response in the growth of Arabidopsis roots. Plant Cell Physiol. 42, 301-307.

Sawar, M. and Kremmer, R.J. 1995. Enhanced suppression of plant growth through production of L-tryptophan compounds by deleterious rhizobacteria. Plant Soil 172, 261-269.

Silva, E.M., Machuca, A., and Milagres, A.M.F. 2005. Effect of cereal brans on Lentinula edodes growth and enzyme activities during cultivation on forestry waste. Lett. Appl. Microbiol. 40, 283-288.

Steenhoudt, O. and Vanderieyden, J. 2000. Azospirillum, a freeliving nitrogen fixing bacterium closely associated with grasses:genetic, biochemical and ecological aspects. FEMS Microbiol. Rev. 24, 487506.

Tien, T.M., Gaskins, M.H., and Hubbell, D.H. 1979. Plant growth substances produced by Azospirillum brasilense and their effect on the growth of pearl millet (Pennisetum americanum L.). Appl. Environ. Microbiol. 37, 1016-1024.

Uhart, M., Piscera, J.M., and Albertó, E. 2008. Utilization of new naturally occurring strains and supplementation to improve the biological efficiency of the edible mushroom Agrocybe cylindracea. J. Ind. Microbiol. Biotechnol. DOI 10.1007/s10295-008-0321-1.

Wang, Y., Han, K.S., Wang, X.Y., Koh, Y.J., and Hur, J.S. 2009. Effect of ribitol and plant hormones on aposymbiotical growth of the lichen-forming fungi of Ramalina farinacea and Ramalina fastigiata. Mycobiology 37, 28-30.

Wang, X.Y., Li, W.X., Luo, H., Kim, J.A., Jeon, H.S., Koh, Y.J., and Hur, J.S. 2010. Plant hormones promote growth in lichen-forming fungi. Mycobiology 38, 176-179.

Wood, D.A. and Hammond, J.B.W. 1977. Ethylene production by axenic fruiting cultures of Agaricus bisporus. Appl. Environ. Microbiol. 34, 228-229.

Xie, H., Pastemak, J.J., and Glick, B.R. 1996. Isolation and characterization of mutants of the plant growth-promoting rhizobacterium Pseudomonas putida GR12-2 that overproduce indoleacetic acid. Curr. Microbiol. 32, 67-71. 